\title{
The German Approach towards the Accesion of Poland and the Czech Republic to the $\mathbf{E U}^{\#}$
}

\author{
Eva Cihelková - Jakub Krč
}

Introduction

Geographical location, economic dimension and development predestinate the Federal Republic of Germany (thereinafter Federal Republic, Germany) to play a very important part in the whole area of Central Europe. With the short excursion to the history, we discover that the relations between German and Slavic ethnicities in our region date back deep to the past. Whether we observe the disputes about territory in between the newly formed state entities, difficult process of diffusion of the western Christianity to the central Europe in $10^{\text {th }}$ and $11^{\text {th }}$ century or the arrival of German settlers to the area of present-day Poland and the Czech Republic during $12^{\text {th }}$ and $13^{\text {th }}$ century we come to the conclusion that their relationships always played an extremely important role. Such situation continued even in the time, when the both sides encountered each other under the common rule within multinational empires and monarchies. In some degree, their relations got complicated during the emancipation and consolidation of particular nations in $19^{\text {th }}$ century, but in spite of the fact that they were difficult during the whole period, we can not forget their positive aspects, which expressed themselves mostly in cultural and economic cooperation that enriched both.

In $20^{\text {th }}$ century the ties between Germany and the two Slavic countries, which were formed for centuries, were violently severed due to two world wars. Central European region was traversed by the Iron Curtain that divided Germany itself into two separate states. Despite a difficult international-political situation and a temporary interruption of diplomatic relations, the bilateral contacts were not completely broken even in the post War period. First important attempt to warm up the relations was represented by negotiations between Federal Republic and People's Republic of Poland in the end of 1960s that led to a completion of Polish-German Treaty on the Foundation of Regulating Relations of 1970 (Vertrag 1970). Analogical negotiations between Czechoslovak Socialist Republic and Federal Republic from 1971 till 1973 concluded with the adoption of the Treaty on Mutual Relations (Smlouva 1973) in December of 1973. Though both documents led to a certain release of mutual relations, the existence of two German states and an ideological and power-strategic border, which went between two blocks in Europe, did not allow any significant cooperation. That fact played an extraordinary role during the Cold War and the so called German Question was a neuralgic point in the East-West relations until its end.

A fundamental German position in Central and East Europe could be fully noticed during the collapses of communistic regimes in the region in the end of 1980s and beginning of

\footnotetext{
This paper was worked out within a framework of the Research Plan of the Faculty of International Relations, University of Economics, Prague, No. MSM 6138439909.

* Prof. Ing. Eva Cihelková, CSc. - head of the Department of World Economy, Faculty of International Relations, University of Economics, Prague, nám. W. Churchilla 4, 13067 Prague 3, Czech Republic; (cihelka@vse.cz). Mgr. Ing. Jakub Krč - Ph.D. fellow, Department of World Economy, Faculty of International Relations, University of Economics, Prague, nám. W. Churchilla 4, 13067 Prague 3, Czech Republic; (jakub.krc@vse.cz).
} 
1990s. Germany began, promptly and actively, with a support for the transformation processes in those countries and after a successful German unification came to an arrangement of the mutual relations on a brand new basis. Relations between Poland and Germany were complicated only by the problems related to the territory disputes and a common border. On the other hand, the present-day Czech Republic and Germany had no such problems. All the more were the bilateral relations influenced by the problem of displaced German population after the World War II., whose shadow was not eliminated, even though a big effort of both partners.

In this respect it is important to mention that the western part of Germany, the Federal Republic was involved in the very beginnings of the European integration and always supported its deepening. That was the way, how the Federal Republic included itself in the political life in the West and its role in the international politics grew during the Cold War all the time. One of the goals of the transformation process of the Czech Republic and Poland was also the accession to the European integration structures. The process of their admissions turned out to be quite a long-term, but without permanent German support, it would be surely leading to a failure.

In the beginning of the $21^{\text {st }}$ century, Germany is with its population of 82.314 million (Eurostat 2007) and an economic power the most important single country within the EU. With respect to the Czech Republic and Poland, Germany is the most important business partner and plays a key role as well as an investor. Poland is with a population of 38.125 million (Eurostat 2007) from far the most inhabited country in Central Europe and its strategic role will probably rise. The Czech Republic belongs among medium size countries (with 10.287 million inhabitants) (Eurostat 2007), but due to the historical ties and the present-day level of bilateral economic cooperation, its position in the region is also significant (Eurostat 2006).

The aim of this paper is to analyze the political principles, expectations and specific approaches that among others influenced the German position towards the accession of Poland and the Czech Republic to the EU. The first part brings a draft of circumstances due to which the mutual confidence was strengthened and therefore allowed to the CEE countries to set off on a track to the EU. The second part outlines the grounds that prepared the conditions for German support of the eastern enlargement. The third one describes the similarities and differences in German approach toward Poland and the Czech Republic and its possible reasons.

\section{What were the grounds for German approach towards Poland and the Czech Republic?}

In 1990, the whole Central Europe found itself in a brand new situation. Communistic regimes had crumbled and Germany was intensively preparing itself for unification, due to which it acquired a common border with Poland and likewise distinctively longer border with the Czech and Slovak Federal Republic ${ }^{1}$. The end of the Cold War constituted new impulse for the development of a mutual cooperation between the two sides. German representatives implied from the beginning that they perceived the collapse of the Soviet Block as an opportunity to involve Poland and Czechoslovakia into the process of European integration (Kohl 1994). Germany has therefore become, in the very beginning of a transformation period, an advocate of these countries, which were naturally striving for

1 Czech and Slovak Federal Republic was an official name of Czechoslovakia from 23rd of April 1990 until 31 st of December 1992 and was created after so called the hyphen war. 
an involvement into European structures and so for they claimed the return to Europe as one of the goals of the transformation process.

Before the process of approaching of the Central and East European (CEE) countries towards the European institutions could begin itself, many necessary steps had to be done in regards to the relations with Germany. Those steps obtained the form of new bilateral treaties that corresponded to the changed situation in Europe. It is already there, where we could notice a certain differentiation of positions of Poland and Czechoslovakia as the German most prominent partners in the region. The most important measures towards Poland were in particular these: the $2+4$ negotiations, subsequent treaty on the recognition of borders of November 1990 and finally treaty on friendship and cooperation of June 1991, which from Polish point of view had the same importance. As mentioned above, there more or less was no problem with border with the Czech and Slovak Federal Republic, but the need for establishing the bilateral relations on new grounds was similarly important. Treaty on good neighborhood and friendly cooperation was signed in 1992. It was followed by quite a specific form of arrangement of the bilateral relations, the Czech-German Declaration on Mutual Relations and their Future Development of 1997. Negotiations and subsequent documents mentioned above represent tools, by which means the bilateral relations were and are arranged and which broke the ground for the later approaching of Poland and the Czech Republic to European structures.

The negotiations on a final settlement with respect to Germany, known as the $2+4$ negotiations, which took place among the two German states and the Four Powers (Soviet Union, United States, United Kingdom and France) and to which Poland was consequently partly included, resulted in treaties that in principle provided for the German unification. The agreement on organizing such negotiations was achieved in January of 1990 in Ottawa during the common session of NATO and Warsaw Treaty. The Treaty on Final Settlement with Respect to Germany (Treaty 1990b) was signed on $12^{\text {th }}$ of September of 1990 in Moscow. Poland entered the negotiation with one main goal. It was the requirement of an international recognition of its western border. Proceedings about those issues were predominantly conducted between Chancellor Kohl and Prime Minister Mazowiecki. Chancellor Kohl initially stood out for the solution that would keep the question of Polish western borders out of negotiations until the German unification was accomplished, which had given rise to skepticism of the Polish delegation. The skepticism was dispersed as late as September of 1990, when the negotiations were crowned after five month of discussions and the Polish western border was recognized according to the international law.

Treaties that followed in 1990 and 1991 smoothed away the bottom qualms and definitely reduced the mutual psychological barrier to the minimum. Treaties became the tools, by which the Polish - German relations could further develop and their cooperation could openly lead towards the integration of Poland to European Communities. First of the concluded treaties was the Polish - German treaty on confirmation of the frontier (Treaty 1990a) of November 1990, which finally resolved the problem of Polish western border. The Treaty was linked to many questions that were related to the loss of property of the German dwellers on the present-day Polish territory. The solution of the property and compensation claims of German citizens was postponed by both sides till later, whereas in fact it has not been done until now. The development of German-Polish relations did not bring back any negative reactions on any side of the border. On the other hand the Treaty on Friendship (Treaty 1991) of 1991 turned out to be more controversial for a particular segment of Polish society. The reason was that Polish government claimed to guarantee extensive rights of the German minority on its territory. Polish society was rather surprised by the acknowledgement of the fact that instead of few thousands that were estimated, 
around 300.000 Germans lived on Polish territory (Beziehungen zwischen Polen und Deutschland). Despite some problems that the acknowledgement caused, the Treaty represented an important step forward on the Polish track to Europe. The fact that Polish side guaranteed the protection and development of the minority rights on its territory meant for German representatives as much as the proof of Polish determination to become a standard European democracy and therefore a respected member of European structures. The Treaty initiated a close Polish-German cooperation, contributed to a significant growth of the bilateral trade and confirmed the German role as an advocate of Polish interests on the road to the European Union. It immediately led in an intensive technical support for the Polish engagement to the European programs such as PHARE.

The first significant document in relations between Germany and Czech and Slovak Federal Republic was the Treaty on Good Neighbourly and Friendly Relations (Smlouva 1992) of 1992, which is in some respects similar to the German-Polish Treaty from the previous year. That document contributed to the mutual confidence, nevertheless many problematic issues were left unsolved and henceforth complicated bilateral relations, which have not developed do dynamically as in the Polish case (Souhrnná teritoriální informace - Spolková republika Německo).

A new attempt to revive the bilateral relations was the adoption of Czech-German declaration on Mutual Relations and their Future Development (Deklarace 1997) in January 1997 that was achieved after many years of negotiations. The outcomes were the consolidation of contacts and cooperation, but the two main questions that complicated the bilateral relations for a long time had not been solved. Those were the role of Sudeten Germans, respectively their collective culpability and displacement and the legal position of the so called Benes Decrees. An advance was embodied in the fact that Germany admitted the responsibility for the development that led to the destruction of Czechoslovakia and the Munich Treaty, expressed deep regrets over the suffering of Czech citizens during the Nazi's occupation and conceded that these facts created the situation, which contributed to the expulsion of German inhabitants after the World War II. In return, Czech government expressed its sorrow over that, how the German minority was treated in the final phase of War and during its displacement. An important role in the further development of bilateral relations was admitted to Sudeten Germans, but they remained skeptical to the significance of the Declaration and their approach approved itself in their activities later during the Czech accession process to the EU. Despite the mentioned drawbacks the Declaration and the further progress that it started both enacted unambiguously positive role. The mutual confidence was strengthened and both countries could evolve effort leading towards the integration of the Czech Republic to the EU.

\section{What were the expectations that constituted the basis for the German approach towards the Eastern enlargement?}

As mentioned above, the membership in international organizations of western type represented more or less the desirable goal of the transformation of the newly formed democracies in CEE, notional return to Europe. It relates naturally to Poland and Czech Republic, which could soon profit from the significant support that was offered by Germany.

In 1999 both countries became members of NATO and therefore they fulfilled one of their particular intentions. Their incorporation into NATO constituted a qualitative change also for their relations to Germany. First of all, they became an equal partner of Germany in political and military spheres. One fact could be considered as even more important. After 
many decades all those states became formally allies and they dispatched any remaining mutual mistrusts and psychological barrier. Their membership in NATO did not evoke any significant negative reactions on any side of the border and it was considered as a confirmation of the principle of collective security under the protection of the United States in Europe.

The accession of CEE countries to the EU turned out to be more difficult and relatively time consuming. Contrary to the involvement in the political-military alliance, it assumed the implementation of all the existing legal acts and norms of the European Community and any attempt to obtain the exception clause was put through careful screening and following discussion on the part of the existing member states. During the process of negotiations about the conditions of the EU membership, some of the bilateral problems appeared and they certainly complicated the process itself and therefore the relations with Germany played a significant role even that time. On the other hand, both sides were convinced all the time about the exceedingly positive contributions of the so called Eastern enlargement of the EU and if some of the long-term problems were not solved yet, they were shifted aside after the time of the accession itself.

From the German point of view, the advantages of the accession of the CEE countries could be divided into few basic groups (A wider Europe - an overview).

First of all, it was important to strengthen further the stability of region along the EU's eastern border. Though the parallel with the situation in Balkans can be distant, the worries about the stability in the region were quite noticeable. German political representation made an effort to enforce the principles of law and democracy in the CEE countries for good and the range of standard European norms was moved further east. The EU membership was also considered as certain mean, how to avoid the nationalistic manias of the past. A significant economic development of the entering countries was assumed and it should have contributed to the lessening of potential migratory pressures on the EU labor markets. Overall, we can assume that the motif of the political stability played the primary role within the German support of the accession process.

Second, the EU enlargement of Poland and the Czech Republic should have brought a significant incentive for the economy of Germany itself. Immediately after the beginning of the transformation of the CEE countries, German firms became the most important investors in whole region and the German role as the most considerable trade partner growth as well. The further development of mutual economic ties was considered as welcomed advantage to the German growth, especially in the German states with high unemployment along its eastern border. As related natural advantage could be viewed an assumed improvement of the infrastructure and therefore easier penetration of German firms further eastwards. For German investors played an important role especially the fact, that the accession of CEE countries to the EU was accompanied with the complete transformation of their systems of law, due to which the corporate environment became more transparent.

Third group of advantages was perceived in the dispersion of fears of a German dominance in Europe, not only in the CEE countries, but even in the existing member states of the EU. The consideration was led in the direction that the enlargement of the EU would lessen the German margin of manoeuvre within the EU. Its eventual attempts at enforcement in the EU would necessarily need wider agreement, in the following even of the CEE countries. On the other hand, the integration of Poland and the Czech Republic would lessen German relative power towards them, though Germany is naturally their strongest neighbor. For Germany itself, the dispersion of all doubts about its potential dominance played an important role and integration of the CEE countries considered as the most suitable tool for it. 
The last reason for German support of the eastern enlargement process was its principal determination to strengthen the European integration, despite of all the short-term disadvantages it could bring. That long-term vision of European consolidation found its important representative in the figure of Chancellor Helmut Kohl, who that aspect of German foreign policy reaffirmed in many of his public speeches. In this respect the German position remained consistent even after his departure.

To sum up the German official approach towards eastern enlargement, it was on principle the German attempt to avoid the potential creation of political vacuum in central Europe and the attempt to strengthen the stability and security on the east of its border. For German representatives, the question did not sound if the EU ought to enlarge, but rather when and under what conditions. Though, the positions of main German political parties towards the EU enlargement slightly varied.

\section{What were the differences in German approach towards both countries?}

In the very beginning of 1990s, Germany tried to answer the changes in CEE countries conceptually and relations to its eastern neighbors develop with more or less same dynamism and intensity. Nevertheless, it did not take long till the German policy towards each country differed that could be clearly documented in the case of Poland and the Czech Republic.

Poland, compared with the Czech Republic, gained soon the priority position in German diplomacy. Germany made an effort to create similar structures and employ analogical forms of reconciliation towards Poland as were used towards France decades ago. In 1991, Chancellor Helmut Kohl initiated a formation of so called Weimar Triangle that was supposed to act as certain basic framework for negotiation among Poland, Germany and France. The project attracted a great medial attention, but its practical outcomes were very limited. The senior officials of the countries hold their meetings on a regular basis, but still their discussions did not bring the expected common positions. The Triangle has become an useful platform for mutual communication, but some of the optimistic expectations about the fundamental role that it could play in the new situation were not completed.

Already during the first years of Polish transformation, the atmosphere in bilateral relations began to be significantly influenced by the institutions standing outside of the official structures of the two countries, but having some sort of ties to Germany. For instance, it was the case of two academic organizations - Polish-German Viadrina European University located in Frankfurt (Oder) (Die Weiterentwicklung der Europa Universität Viadrina Frankfurt) and Willy Brandt Centre at the Wroclaw University. On the other hand, there was no similar institution of that range acting in the Czech Republic, though many unofficial activities took place after 1997 within the framework of Czech-German Future Fund. That difference can bear certain importance for the understanding of a different level of bilateral relations. It is visible, that relations to Poland embodied significantly higher dynamics that to the Czech Republic.

The endeavor of Germany and other western European countries to involve the CEE region closer to the European Communities led in the creation of a special program for financing of an accession support, PHARE. That program was initially aimed at Poland and Hungary, but it was soon extended for the other candidate countries. In 1992, the completion of European Treaties with Poland, Hungary and the present-day still existing 
Czech and Slovak Federal Republic followed. The formal negotiations about the accession began simultaneously with Poland and the Czech Republic in March of 1998 and were accomplished in November of $2002^{2}$. Both countries entered the EU in May of 2004 after successful referendums. From this point of view the accession process of both countries could be considered as analogical and therefore it could be supposed that the German approach towards them was more or less similar. This conclusion would be though an improper simplification of the issue, which would miss out a significant differentiation in German relations to its eastern neighbors.

During the accession negotiations, some of the unsolved bilateral problems appeared and their solution varied state to state. Germany reassured its eastern neighbors about the fact that it would not support, at official level and in any case, any claims of German expellees to any form of financial compensation. On the other hand, German side supposed that as a part of the accession process to the EU the Czech Republic, resp. Poland themselves would make an effort to come up to their past and they would manifest a sort of a conciliating gesture towards their former citizens of German nationality. It was soon clear that governments of both countries did not consider anything similar and a subject of displaced Germans remained very controversial even after many decades. Those questions in connection with incomparable purchasing power of German citizens led to the transition periods that were carried through by both candidate countries on purchases of farmland by foreigners. The period will last as far as twelve years in a case of Poland and in the case of the Czech Republic as far as seven years. Fears of the citizens of new member states of the potential land rush in borderland by expelled Germans were in an absolute majority based on the groundless phobia, which with the closer look at the problem lost its pressure. Analogical psychological fear could be seen on the German side as well. During the negotiations, Germany stood with power for the transition period for the opening of the EU labor markets to the new member states. That approach rose from the worries that were brought back by the cheap labor force in the east of German borders. The outcome was the transition period on the free movement of labor force for the next seven years with a theoretical possibility of its shortening from the German side. All the fears rose from a certain stereotype reception of reality and were not based on the rational analysis of potential risks.

Topics mentioned above, therefore free movement of labor and capital, represent the only major problematic spots in relations of Poland and the Czech Republic towards Germany that arose. On the track to the EU they constituted unpleasant, but not fundamental obstructions. It was displayed especially in the case of the Czech Republic, when members of the European Parliament of the Christian Social Union (CSU) voted against the admission of the Czech Republic to the EU, justified by the fact that the Czech Republic did not annul the so called Benes Decrees ${ }^{3}$. It was of no effect on the final outcome of the vote, nevertheless it shows still unsolved issues in bilateral relations.

\section{Conclusion}

A new period in mutual relations arose after the end of the Cold War and the following the unification of two German states. Evolving bilateral cooperation corresponded to the situation in Central Europe. It culminated with the completion of international treaties

2 The negotiations before and during the accession of the CEE countries to the EU, as well as the process of their adaptation to the conditions of the EU membership were analyzed in detail in (Cihelková 2003: 569-616).

3 More in (Domnitz 2007). 
between Germany on one side and Poland, resp. Czechoslovakia on another. Some, from the historical point of view problematic issues in bilateral relations were solved within these treaties, especially the question of German eastern border.

An intensive cooperation in 1990s could be noticed particularly in the area of trade and investments, but with the forthcoming opening of accession negotiations between the EU and Poland and Czech Republic, the bilateral political relations developed positively as well. That stage culminated with the accomplishment of the so called Czech-German Declaration of 1997.

Despite of some of the unsolved issues in German relations towards Poland, resp. Czech Republic, Germany was a significant supporter of accession of CEE countries to the EU and its assistance was invaluable. German basis for its position to the admission of CEE countries could be seen above all at an attempt to strengthen the area of security and stability in the East of its borders. The encouragement of an economic cooperation and full utilization of possibilities that opened to the German economy with the EU enlargement were important aspects as well. There arose only two problematic questions within the negotiations. They were solved by two transition periods, for free movement of labor and free movement of capital. However, the solutions of those problems did not influence the fundamental determination of German political representation to support the accession of the CEE countries to the EU.

Despite of the fact that both countries came through the same process of accession negotiations with the analogical results, their position within an approach of German diplomacy can not be considered as identical. Poland benefited, and still is, from more significant support, resp. their relations are more intensive. First signs of different German approach towards Poland could be noticed already during the so called negotiations $2+4$ and following attempt to establish the Weimar Triangle proved that tendencies. It was intensified by the fact that some of the issues, which were still controversial on the Czech side, were solved on the Polish one. That differentiation was as well represented by the diverse level of cooperation at academic spheres, whereas unambiguously more active relations could be noticed between Poland and Germany. Neither the completion of Czech-German Declaration and creation of Czech-German Future Fund, despite their indisputable positive effects, had changed that status.

With the accession of Poland and the Czech Republic to the EU in May of 2004, all three countries became members of one common legal and economic area and mutual relations entered a new qualitative level. Many new opportunities and possibilities opened to them and their fulfillment is completely in their hands. Many long-time problematic issues in bilateral relations were eased off, or their negative impact was minimized. Bilateral business ties are developing in a positive way as well as the investment activities of German companies on the territory of both states. All three countries cooperate within the framework of the EU on the solution of the same problems, which represent, despite of their significantly different economic size, the same challenges for the future. These problems have in many cases a global extent and an international cooperation is therefore needed.

The accession of both countries to the EU represents without any question an unique opportunity for the further development of Polish-German and Czech-German relations, because within the EU membership they can together lead up to the solution of all remaining problems. 


\section{References}

A wider Europe - an overview.

http://www.auswaertiges-amt.de/diplo/en/Europa/Erweiterung/Erw-Uebersicht.html.

Beziehungen zwischen Polen und Deutschland.

http://www.auswaertiges-amt.de/diplo/de/Laenderinformationen/Polen/Bilateral.html\#t5

CIHELKOVÁ, E. (2003). Vnějši ekonomické vztahy Evropské unie. Praha : Nakladatelství C. H. Beck, 2003, s. 569-616.

CORDELL, K.; WOLFF, S. (2005). Germany's Foreign Policy Towards Poland and the Czech Republic. Oxon : Routledge, 2005.

Deklarace (1997). Česko-německá deklarace o vzájemných vztazích a jejich budoucím rozvoji. http://www.mzv.cz/wwwo/mzv/default.asp?id=26316\&ido=14070\&idj=1\&amb=1.

Die Weiterentwicklung der Europa-Universität Viadrina Frankfurt .

http://www.euv-frankfurt-o.de/de/ueber_uns/portrait/positionspapier.pdf.

DOMNITZ, CH. (2007). Zápas o Benešovy dekrety před vstupem do Evropské unie. Praha : Dokořán, 2007.

Eurostat (2006). External and intra-European Union trade. http://epp.eurostat.ec.europa.eu/cache/ITY_OFFPUB/KS-CV-06-002/EN/KS-CV-06-002-EN.PDF

HANDL, V. - HON, J. - PICK, O. a kol. (1998). Vztahy SRN ke státům střední Evropy. Praha : Ústav mezinárodních vztahů, 1998.

KOHL, H. (1994). Společná politika pro Evropu. In Sborník projevů k evropské integraci. Praha : Ústav mezinárodních vztahů, 1994.

MÜLlER, H. (1995). Dějiny Německa. Praha : Nakladatelství Lidové noviny, 1995.

Eurostat (2007). Population and social conditions, Total population.

http://epp.eurostat.ec.europa.eu/portal/page? pageid=1996,39140985\&_dad=portal\& schema $=$ PORTAL\&screen $=$ detailref\&language $=$ en \&product $=$ Yearlies_new population\&root=Yearlies_new_population/C/C1/C11/caa10000

Smlouva (1992). Smlouva mezi Spolkovou republikou Německo a Českou a Slovenskou federativní republikou o dobrém sousedství a prátelské spolupráci.

http://www.germanembassy.cz/EN/POLITIK_PRESSE/BILAT_BEZ/bstvertrag92_cz.html.

Souhrnná teritoriální informace - Spolková republika Německo .

$\mathrm{http} / /$ www.mzv.cz/wwwo/mzv/stat.asp?StaID=F2AA84FD-B9A7-4200-A917-0FA2DA08DDF4.

ŠAUER, J. (2005). Německá otázka v epropské politice. Praha : Oeconomica, 2005.

Treaty (1990a). Treaty between the Federal Republic of Germany and the Republic of Poland on confirmation of the frontier between them. http://www.un.org/Depts/los/LEGISLATIONANDTREATIES/PDFFILES/TREATIES/ DEU-POL1990CF.PDF.

Treaty (1990b). Treaty on the Final Settlement with Respect to Germany. http://usa.usembassy.de/etexts/2plusfour8994e.htm.

Treaty (1991). Treaty on Friendship and Good Neighbourly Relations . http://ambasadaniemiec.pl/files/Vertrag17.6.91-dt.pdf.

Vertrag (1970). Vertrag zwischen der Bundesrepublik Deutschland und der Volksrepublik Polen über die Grundlagen der Normalisierung ihrer gegenseitigen Beziegungen. http://www.auswaertigesamt.de/diplo/de/Europa/DeutschlandInEuropa/BilateraleBezie hungen/Polen/Vertraege/WarschauerVertrag.pdf. 
Smlouva (1973). Vyhláška ministra zahraničních věcí o Smlouvě o vzájemných vztazích mezi Československou socialistickou republikou a Spolkovou republikou Némecka. http://www.mvcr.cz/sbirka/1974/sb17-74.pdf.

\title{
The German Approach towards the Accesion of Poland and the Czech Republic to the EU
}

\author{
Eva Cihelková - Jakub Krč
}

\begin{abstract}
The Geopolitical divide that separated Europe did not allow Germany on one side and Poland and Czechoslovakia on the other side to prosper from the potential of their relations. It has rapidly changed after the end of the Cold War, when both sides concluded and began to engage in many bilateral and multilateral treaties and cooperation that culminated in 2004 with the eastern enlargement of the EU. This paper deals with the German approach towards Poland and the present-day Czech Republic at bilateral as well as multilateral level during and before the enlargement itself and combines both political and economic points of view. The outline is based on examination of essential political documents and their further practical effects. The analysis of German approach is based on the characteristic of bilateral relations of the Federal Republic of Germany to the both countries, German incentives for enlargement of the EU as well as different intensity of relations of respected countries.
\end{abstract}

Key words: Germany; Poland; Czech Republic; EU Enlargement; International Relations. JEL classification: F02

\section{Přístup Německa k rozšíření Evropské unie o Polsko a Českou republiku}

\begin{abstract}
Abstrakt
Geopolitická hranice, která rozdělovala Evropu, znemožňovala, aby Německo na jedné straně a Polsko, resp. Československo na straně druhé využily potenciálu vzájemných vztahů. Zásadní změna nastala po skončení studené války, kdy se obě strany dohodly a začaly realizovat řadu dvoustranných i mnohostranných smluv a forem spolupráce, což vyvrcholilo $\mathrm{v}$ roce 2004 východním rozšířením EU. Tato stat' se zabývá německým př́stupem $\mathrm{k}$ Polsku a dnešní České republice na dvoustranné i mnohostranné úrovni před a během př́stupového procesu, a to z politického i ekonomického pohledu. Nástin vztahů je založen na zkoumání základních politických dokumentů a jejich následných praktických efektů. Základem rozboru německého př́stupu se stala charakteristika bilaterálních vztahů Spolkové republiky Německo a obou středoevropských zemí, německých motivů pro rozšíření EU, jakož i rozdílů v přístupu k jednotlivým zemím.
\end{abstract}

Klíčová slova: Německo; Polsko; Česká republika; rozššření EU; mezinárodní vztahy. 